\title{
New net-winged beetles (Coleoptera: Lycidae) from northern Indochina and China
}

\author{
Новые краснокрылы (Coleoptera: Lycidae) из северного \\ Индокитая и Китая
}

\author{
Sergey V. Kazantsev \\ C.В. Казанцев
}

Insect Centre, Donetskaya 13-326, Moscow 109651, Russia. E-mail: kazantss@mail.ru Инсект-центр, ул. Донецкая 13-326, Москва 109651, Россия.

KEY WORDS: Coleoptera, Lycidae, new species, Oriental and Palaearctic regions.

КЛЮЧЕВЫЕ СЛОВА: Coleoptera, Lycidae, новые виды, Ориентальная и Палеарктическая области.

\begin{abstract}
Ten new species of net-winged beetles, Dictyoptera prosvirovi, Lycoprogentes rubicundus, L. grootaerti, L. bonaparte, L. holzschuhi, L. aurantiacus, Xylobanellus cerasinus, X. rubeus, Dilophotes umbellifer and Lyponia (Weiyangia) simplex, spp.n., are described from Indochina and China. The previously unknown male of Helcophorus angustatus (Pic, 1929) is illustrated.
\end{abstract}

РЕЗЮМЕ. Из Индокитая и Китая описывается десять новых видов жуков-краснокрылов: Dictyoptera prosvirovi, Lycoprogentes rubicundus, L. grootaerti, L. bonaparte, L. holzschuhi, L. aurantiacus, Xylobanellus cerasinus, $X$. rubeus, Dilophotes umbellifer и Lyponia (Weiyangia) simplex spp.n. Приводятся иллюстрации прежде неизвестного самца вида Helcophorus angustatus (Pic, 1929).

\section{Introduction}

In the new lycid material from Laos, Thailand, Vietnam and China several new or very rare species from the genera Helcophorus Fairmaire, 1891, Dictyoptera Latreille, 1829, Lycoprogentes Pic, 1915, Xylobanellus Kleine, 1930, Dilophotes Waterhouse, 1878 and Lyponia Waterhouse, 1878 were found. Dilophotes, Lycoprogentes and Xylobanellus are mostly oriental, with only few species known in the Palaearctic region from each [Kleine, 1933; Bocáková \& Bocák, 2007]; on the contrary, Helcophorus and Lyponia are predominantly Palaearctic, with just one species of the former and two of the latter occurring beyond the limits of the region [Kazantsev, 1996, 2002, 2004]. Dictyoptera is Holarctic, however seven of its 18 species occur in northern Indochina, thus extending the distribution area of the genus to the Oriental region [Kazantsev, 2013]. Helcophorus is also one of the lycid genera reported from the Baltic amber [Kazantsev, 2013].
Presented below are descriptions of the new taxa, as well as illustrations of the poorly known representative of the genus Helcophorus of which no males have so far been seen.

\section{Material and Methods}

The studied specimens were glued on cardboard plates. For a detailed examination they were relaxed in water; then the ultimate abdominal segments were treated for several hours in $10 \% \mathrm{KOH}$ at room temperature, then, with the extracted genitalia, placed in microvials with glycerin.

MSP-1 zoom stereoscopic dissecting microscope with $\mathrm{x} 8-\mathrm{x} 80$ magnification range was used. Photographs were taken with Canon EOS 6D camera and Canon MP-E $65 \mathrm{~mm}$ lens.

The following acronyms are used in the paper: ICM - Insect Center, Moscow; IRSN — Institut Royal de Sciences naturelles de Belgique, Bruxelles.

\section{Taxonomy}

$$
\text { Helcophorus angustatus (Pic, 1915) }
$$

Figs $1-4$

Dictyopterus angustatus Pic, 1929: 7.

Pyropterus angustatus (Pic, 1929): Bocák \& Bocáková, 1991: 187. Pyropterus (Helcophorus) angustatus (Pic, 1929): Kazantsev, 1996: 83

Helcophorus angustatus (Pic, 1929): Kazantsev, 2004: 43.

MATERIAL: $\sigma^{7}$, N Vietnam: Lai Chau prov., Hoang Lien Son N.P., $1980-2070 \mathrm{~m}, 22.338^{\circ} \mathrm{N}, 103.779^{\circ} \mathrm{E}, 7 . \mathrm{V} .2013$, A. Prosvirov leg.; + , E Laos, Hua Phan prov., Ban Saleui, Phou Pan Mt., $20^{\circ} 122 \mathrm{~N}$, $104^{\circ} 01^{\prime} \mathrm{E}, 1300-1900 \mathrm{~m}, 1-31.05 .2011$, C. Holzschuh leg. (ICM).

REMARKS. Helcophorus angustatus has so far been known by one specimen, the female lectotype from «Lao Kay», deposited at the Paris Museum of Natural History [Bocák \& Bocáková, 1991]. The male of this species differs from $H$. miniatus Fairmaire, 1891, in addition to the coloration, by the more produced and acute hind angles of the 
metatrochanters (Fig. 2) and wider parameres of the aedeagus (Figs 3-4). Whereas Bocák and Bocáková signaled uniform- ly orange red legs in the specimen they studied, both the male and the female at my disposal have black tarsi (Figs 1-2).


Figs 1-4. Helcophorus angustatus, male: $1-2-$ general view; $3-4$ - aedeagus; 1 - dorsally; $2-3$ - ventrally; $4-$ laterally. Scale: $0.5 \mathrm{~mm}$.

Рис. 1-4. Helcophorus angustatus, самец: 1-2 - общий вид; 3-4-эдеагус; 1 - сверху; 2-3 - снизу; 4 - сбоку. Масштабная линейка: 0.5 мм.

\section{Dictyoptera prosvirovi Kazantsev sp.n. Figs 5-7}

MATERIAL: Holotype, $\mathrm{O}^{\top}, \mathrm{N}$ Vietnam: Lai Chau prov., Hoang Lien Son N.P., $1980-2070 \mathrm{~m}, 22.338^{\circ} \mathrm{N}, 103.779^{\circ} \mathrm{E}, 30 . \mathrm{IV} .2013$, A. Prosvirov leg. (ICM).

DESCRIPTION. Male. Dark brown; head, pronotal margins and carinae and elytra red.

Vertex flat, densely and finely punctate. Eyes small, interocular distance ca. 2.1 times greater than eye diameter. Ultimate palpomeres slender, elongate, flattened and slightly widened distally. Antennal sockets separated by minute lamina. Antennae filiform, antennomere 9 attaining to elytral third; antennomere 2 transverse, 1.7 times shorter than antennomere 3; antennomere 3 ca. 2.3 times shorter than antennomere 4; antennomere 4 and consequent antennomeres with moderately long dense semi-erect pubescence (Fig. 5).

Pronotum transverse, ca. 1.5 times as wide as long, bisinuate basally, almost straight anteriorly, with almost parallel sides and small acute laterally posterior angles; anterior portion of median areole ca. twice as long as posterior portion and conspicuously broader than it, posterior ribs noticeably concave; straight lateral carinae complete and well developed; postero-lateral roundish impressions prominent. Scutellum subquadrate, slightly narrowing distally, almost truncate at apex (Fig. 5).

Elytra long, 3 times longer than wide at humeri, slightly widening distally, with four fully developed primary costae; interstices with double rows of irregular pentagonal cells; pubescence along costae short (Fig. 5).

Aedeagus with distally bent and apically flattened and dilated laterally median lobe; parameres roundish, with spinose ventral lobes; phallobase elongate, symmetric, ca. 0.7 times length of parameres (Figs 6-7).

Female. Unknown.

Length: $7.6 \mathrm{~mm}$. Width (humerally): $2.0 \mathrm{~mm}$.

ETYMOLOGY. The new species is named after Dr. A. Prosvirov (Moscow), who collected its type specimen along with many other interesting cantharoids during his 2013 expedition to Lao Kay and Lai Chau provinces in northern Vietnam.

DIAGNOSIS. Dictyoptera prosvirovi sp.n. seems to be related to D. sapporensis Kôno, 1932 from Japan and South 
Kurils, also with roundish parameres and bent median lobe of the aedeagus, differing by the red head, spinose ventral lobes

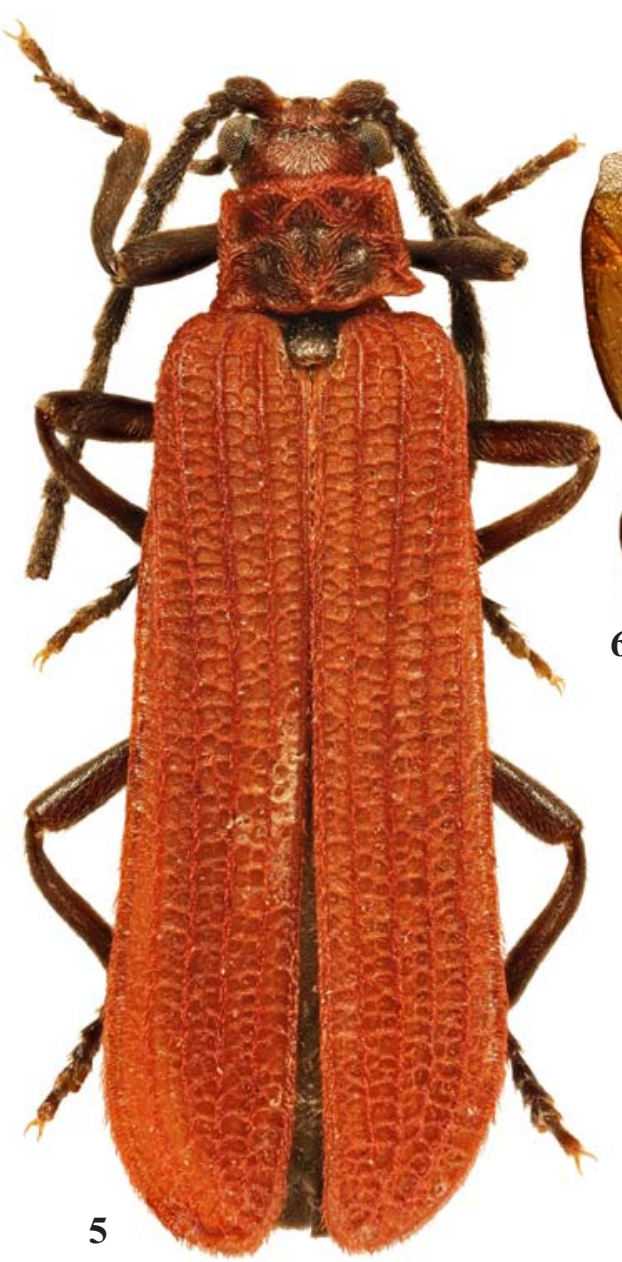

of the parameres and dilated laterally apex of the median lobe of the aedeagus (Figs 6-7).

Figs 5-9. Dictyoptera and Lycoprogentes, holotype males: 5-7 - D. prosvirovi sp.n.; 8-9 — L. rubicundus sp.n.; 5, 8 general view; 6-7, 9 - aedeagus; 5,8 - dorsally; 6, 9 - ventrally; 7 - laterally. Scale: $0.5 \mathrm{~mm}$.

Рис. 5-9. Dictyoptera и Lycoprogentes, голотипы, самцы: 5-7 - D. prosvirovi sp.n.; 8-9 - L. rubicundus sp.n.; 5, 8- общий вид; 6-7, 9 - эдеагус; 5, 8- сверху; 6, 9- снизу; 7 - сбоку. Масштабная линейка: 0.5 мм.

\section{Lycoprogentes rubicundus Kazantsev sp.n. \\ Figs 8-9}

MATERIAL: Holotype, $\sigma^{\top}$, E Laos, Hua Phan prov., Ban Saleui, Phou Pan Mt., $\sim 20^{\circ} 122 \mathrm{~N}, 104^{\circ} 01^{\prime} \mathrm{E}, 1300-1900 \mathrm{~m}, 1-31.05 .2011$, C. Holzschuh leg. (ICM); paratype, $\sigma^{7}$, same label (ICM).

DESCRIPTION. Male. Dark brown; pronotum, except at disk and elytra reddish brown; antennomere 2 distally light brown.

Vertex flat, finely and densely punctate. Eyes small, interocular distance ca. 1.6 times greater than eye diameter. Ultimate palpomeres slightly longer than wide, widening and flattened distally. Antennal sockets separated by minute lamina. Antennae attaining to elytral three fourths, noticeably narrowing distally; antennomeres 4-9 flattened and dentate; antennomere 2 about as long as wide and ca. 1.5 times shorter than antennomere 3 ; antennomere 3 ca. 2.4 times shorter than antennomere 4, antennomeres 4-11 with short dense erect pubescence (Fig. 8).

Pronotum transverse, ca. 1.5 times as wide as long, feebly bisinuate basally and convex anteriorly, with almost straight sides and acute posterior angles; median areole shaped with straight narrow ribs, with anterior ribs meeting at anterior margin and posterior ribs relatively broadly connected to posterior margin; lateral carinae straight, narrow and complete. Scutellum subquadrate, parallel-sided, deeply emarginate at apex (Fig. 8).

Elytra long, 3.6 times longer than wide at humeri, parallelsided, with primary costa 1 indistinguishable from secondary ones in distal half; interstices with rows of small regular mostly elongate cells; pubescence short, dense and erect (Fig. 8).

Aedeagus with dilated and triangular distally median lobe; parameres elongate, concave laterally, with narrow inwardly curved distal horns; phallobase elongate, conspicuously twisted, ca. 0.8 times length of parameres (Fig. 9).

Female. Unknown.

Length: 7.2-8.0 mm. Width (humerally): $2.6-2.8 \mathrm{~mm}$.

ETYMOLOGY. The name of the new species is derived from the Latin for «red», alluding to its coloration.

DIAGNOSIS. Lycoprogentes rubicundus sp.n. may be distinguished from the somewhat similarly coloured $L$. au- 
rantiacus sp.n. by the less orange tint of the upperside, darker pronotum, narrower posterior part of the pronotal areole (Fig. 8 ), as well as by the horned distally parameres, dilated distally median lobe and twisted phallobase (Fig. 9).

\section{Lycoprogentes grootaerti Kazantsev sp.n.} Figs 10-11

MATERIAL: Holotype, $\sigma^{7}$, China, Guangdong, Nanling, Ruyuan, secondary forest, $500 \mathrm{~m}, 08$. V.2004, P. Grootaert leg. (IRSN).

DESCRIPTION. Male. Dark brown; elytral borders and costae at shoulders reddish brown; elytral pubescence reddish.

Vertex flat, densely and finely punctate. Eyes relatively small, interocular distance ca. 1.3 times greater than eye diameter. Labrum transverse, heart-shaped. Ultimate palpomeres robust, securiform, slightly longer than wide. Antennal sockets separated by minute lamina. Antennae attaining to elytral four fifths, noticeably narrowing distally; antennomeres 4-7 flattened and feebly dentate; antennomere 2 transverse, 1.8 times shorter than antennomere 3; antennomere 3 ca. 2.2 times shorter than antennomere 4; antennomeres 4-11 with moderately long dense semi-erect pubescence (Fig. 10).

Pronotum transverse, ca. 1.5 times as wide as long, trapezoidal, feebly bisinuate basally, convex anteriorly, with acute strongly produced laterally posterior angles; median areole broadly connected to anterior and posterior margins, with straight posterior ribs; lateral carinae complete and well developed. Scutellum elongate, concave, almost parallelsided, noticeably emarginate at apex (Fig. 10).

Elytra long, 3.8 times longer than wide at humeri, parallel-sided, with primary costae 1, 2 and 4 hardly distinguisha- ble from secondary ones in distal half; interstices with even rows of small subquadrate cells; pubescence short, dense and erect (Fig. 10).

Aedeagus with arrowhead-like apex of median lobe and elongate; parameres almost parallel-sided, with narrow inwardly curved distal horns; phallobase elongate, ca. 0.8 times length of parameres (Fig. 11).

Female. Unknown.

Length: $7.0 \mathrm{~mm}$. Width (humerally): $1.7 \mathrm{~mm}$.

ETYMOLOGY. The new species is named after Dr. P. Grootaert (Brussels), who collected the type specimen.

DIAGNOSIS. Lycoprogentes grootaerti sp.n. may be differentiated from L nigrostriatus (Kleine, 1926), the only other Lycoprogentes species registered in China, including Taiwan, by the almost uniformly dark brown elytra covered with reddish pubescence (Fig. 10), as well as by the arrowhead-like apex of the median lobe and conspicuously narrower distal horns of the parameres of its aedeagus (Fig. 11).

\section{Lycoprogentes bonaparte Kazantsev sp.n.} Figs 12-13

MATERIAL: Holotype, $0^{7}$, E Laos, Hua Phan prov., Ban Saleui, Phou Pan Mt., $20^{\circ} 122 \mathrm{~N}, 104^{\circ} 01^{\prime} \mathrm{E}, 1300-1900 \mathrm{~m}, 1-31.05 .2011$, C. Holzschuh leg. (ICM).

DESCRIPTION. Male. Dark brown; elytral outer margins and pubescence reddish brown.

Vertex with shallow transverse impression, very finely punctate. Eyes small, interocular distance twice as long as eye diameter. Ultimate palpomeres widening distally, noticeably longer than wide. Antennal sockets separated by minute lamina. Antennae attaining to elytral four fifths, slightly
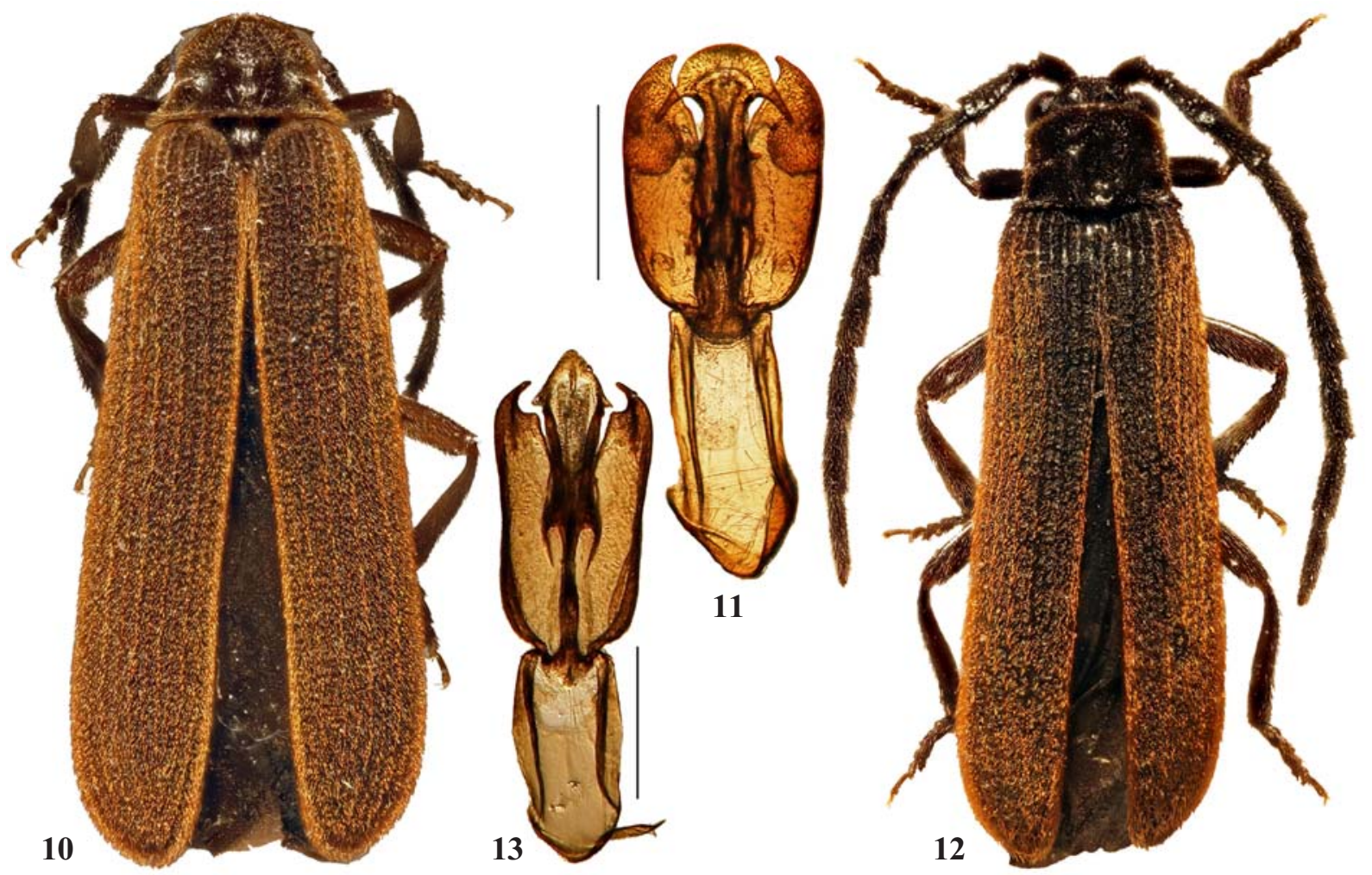

Figs 10-13. Lycoprogentes, holotype males: 10-11 - L. grootaerti sp.n.; 12-13 - L. bonaparte sp.n.; 10, 12 - general view, dorsally; 11,13 - aedeagus ventrally. Scale: $0.5 \mathrm{~mm}$.

Рис. 10-13. Lycoprogentes, голотипы, самцы: 10-11 - L. grootaerti sp.n.; 12-13 - L. bonaparte sp.n.; 10, 12 - общий вид, сверху; 11,13 - эдеагус, снизу. Масштабная линейка: 0.5 мм. 
narrowing distally; antennomeres 4-8 flattened and feebly dentate; antennomere 2 transverse, 2.7 times shorter than antennomere 3; antennomere 3 ca. 2.5 times shorter than antennomere 4; antennomeres 4-11 with moderately long dense semi-erect pubescence (Fig. 12).

Pronotum transverse, ca. 1.6 times as wide as long, almost straight basally, slightly convex anteriorly, with almost parallel sides and small acute produced laterally posterior angles; median areole with anterior ribs narrow and obsolete near anterior margin and directed as if going to meet before it, posterior ribs bulky; lateral carinae obsolete near median areole. Scutellum elongate, parallel-sided, deeply emarginate at apex (Fig. 12).

Elytra long, 3.3 times longer than wide at humeri, parallel-sided, with primary costa 1 hardly distinguishable from secondary ones in distal half; interstices with rows of small irregular subquadrate cells; pubescence short, dense and erect (Fig. 12).

Aedeagus with bicorne-hat-like apex of median lobe; parameres relatively short, with slightly inwardly curved pointed apices; phallobase elongate, subequal in length to parameres (Fig. 13).

Female. Unknown.

Length: $6.6 \mathrm{~mm}$. Width (humerally): $1.5 \mathrm{~mm}$.

ETYMOLOGY. The name of the new species is derived from the noun (Napoleon)Bonaparte, alluding to the resemblance of the apex of the median lobe of its aedeagus to the bicorne hat associated typically with the aforesaid historical figure.

DIAGNOSIS. Lycoprogentes bonaparte sp.n. may be differentiated from other members of the genus by the bicornehat-like apex of the median lobe of the aedeagus (Fig. 13).

\section{Lycoprogentes holzschuhi Kazantsev sp.n. Figs 14-15}

MATERIAL: Holotype, $\bigcirc^{7}$, E Laos, Hua Phan prov., Ban Saleui, Phou Pan Mt., $20^{\circ} 122 \mathrm{~N}, 104^{\circ} 01^{\prime} \mathrm{E}, 1300-1900 \mathrm{~m}, 1-31.05 .2011$, C. Holzschuh leg. (ICM); paratype, $\circ$, same label (ICM).

DESCRIPTION. Male. Dark brown; pronotum, except at disk, scutellum distally and elytra orange testaceous; antennomere 2 and antennomere 11 distally light brown.

Vertex shallowly concave, finely punctate, with narrow median groove. Eyes relatively large, interocular distance subequal to eye diameter. Ultimate palpomeres elongate, slender, slightly widening and flattened distally. Antennal sockets separated by minute lamina. Antennae attaining to elytral three fourths, noticeably narrowing distally; antennomeres 4-7 slightly flattened; antennomere 2 slightly wider than long and twice as short as antennomere 3; antennomere 32.5 times shorter than antennomere 4, antennomeres 4-11 with moderately long dense semi-erect pubescence (Fig. 14).

Pronotum transverse, ca. 1.35 times as wide as long, bisinuate basally and strongly convex anteriorly, with almost straight sides and small acute, produced posterior-laterally posterior angles; median areole noticeably narrower posteriorly, with straight anterior ribs meeting at anterior margin and slightly concave and broadly connected to posterior margin posterior ribs; lateral carinae narrow and complete. Scutellum subquadrate, parallel-sided, deeply emarginate at apex (Fig. 14).

Elytra long, 3.7 times longer than wide at humeri, parallelsided, with primary costa 1 indistinguishable from secondary ones in distal half; interstices with rows of small regular mostly elongate cells; pubescence short, dense and erect (Fig. 14).

Aedeagus with semi-oval distally and not constricted before apex median lobe, bearing one small latero-dorsal dent at each side; parameres short and not constricted proxi- mally; phallobase elongate, 1.25 times length of parameres, noticeably asymmetric, with slender apodemes (Fig. 15).

Female. Similar to male, but larger, eyes smaller and antennae shorter.

Length: $8.8-11.7 \mathrm{~mm}$. Width (humerally): $2.0-2.8 \mathrm{~mm}$.

ETYMOLOGY. The new species is named after Dr. C. Holzschuh (Villach), who collected its type series, along with several other new lycid species described in this paper, in the Phou Pan mountains in Laos.

DIAGNOSIS. Lycoprogentes holzschuhi sp.n. may be distinguished from $L$. aurantiacus sp.n. by the duller orange of the upperside and shorter antennae (Fig. 14), as well as by the shorter and not constricted proximally parameres, not constricted before apex median lobe with one small laterodorsal dent at each side and slender apodemes of the conspicuously asymmetric phallobase (Fig. 15).

\section{Lycoprogentes aurantiacus Kazantsev sp.n.} Figs 16-17

MATERIAL: Holotype, $0^{7}$, NE Thailand, Loei prov., Phu Kradung N.P., $16^{\circ} 522 \mathrm{~N}, 101^{\circ} 49^{\prime} \mathrm{E}, 1000 \mathrm{~m}, 16-7 . V .1999$, D. Hauck leg. (ICM); paratypes: $4 \mathrm{O}^{7} \mathrm{O}^{7}, 2$ 우, same label (ICM).

DESCRIPTION. Male. Dark brown; pronotum, scutellum and elytra orange; antennomere 2 light brown.

Vertex finely punctate, with transverse impression. Eyes moderately large, interocular 1.25 times greater than eye diameter. Ultimate palpomeres elongate, slender, slightly widening and flattened distally. Antennal sockets separated by minute lamina. Antennae attaining to elytral seven eighths, slightly narrowing distally; antennomeres $4-8$ flattened and slightly dentate; antennomere 2 slightly wider than long and twice as short as antennomere 3; antennomere 32.5 times shorter than antennomere 4 , antennomeres $4-11$ with moderately long dense semi-erect pubescence (Fig. 16).

Pronotum transverse, ca. 1.4 times as wide as long, almost straight basally and strongly convex anteriorly, with straight sides and small acute, produced laterally posterior angles; median areole with straight anterior ribs meeting at anterior margin and convex and broadly connected to posterior margin posterior ribs; lateral carinae narrow and complete. Scutellum subquadrate, parallel-sided, deeply emarginate at apex (Fig. 16).

Elytra long, 3.3 times longer than wide at humeri, parallel-sided, with primary costa 1 indistinguishable from secondary ones in distal half; interstices with rows of small regular mostly elongate cells; pubescence short, erect and very dense (Fig. 11).

Aedeagus with cone-shaped apex of median lobe, noticeably constricted distally; parameres elongate, constricted proximally, with small distal dents and a pair of latero-dorsal dents at each side; phallobase elongate, ca. 0.8 times length of parameres, slightly asymmetric, with robust apodemes (Fig. 17).

Female. Similar to male, but eyes smaller and antennae shorter.

Length: $5.0-10.2 \mathrm{~mm}$. Width (humerally): $1.3-2.5 \mathrm{~mm}$.

ETYMOLOGY. The name of the new species is derived from the Latin for «orange», alluding to the coloration of its upperside.

DIAGNOSIS. Lycoprogentes aurantiacus sp.n., apparently related to L. holzschuhi sp.n., is readily distinguishable by the brighter orange of the upperside, longer antennae and broader posterior part of the pronotal areole (Fig. 16), as well as by the more elongate and constricted proximally parameres, constricted distally median lobe with a pair of laterodorsal dents at each side and noticeably more robust apodemes of the somewhat less asymmetric phallobase (Fig. 17). 


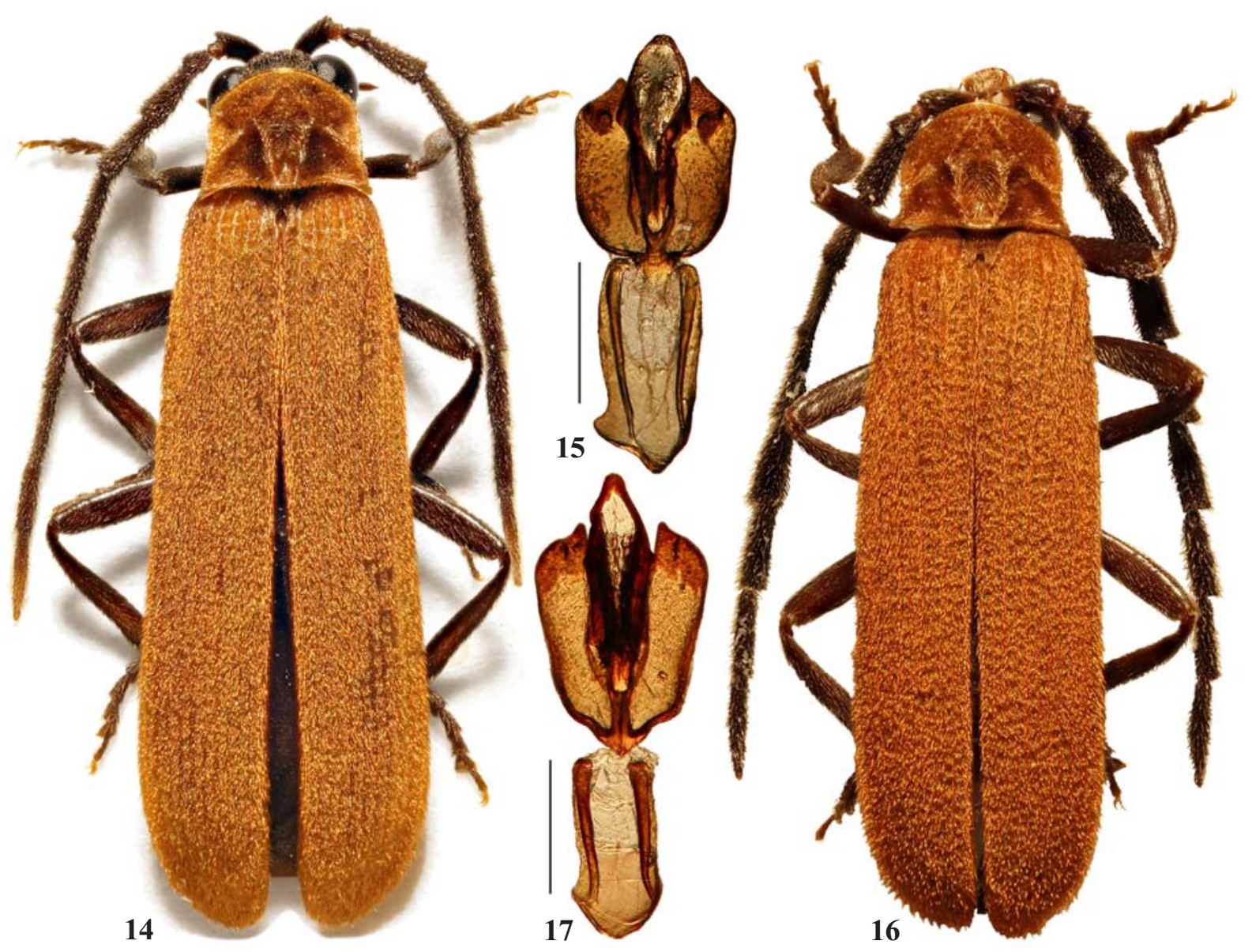

Figs 14-17. Lycoprogentes, holotype males: 14-15 - L. holzschuhi sp.n.; 16-17 — L. aurantiacus sp.n.; $14,16-$ general view; 15,17 - aedeagus ventrally. Scale: $0.5 \mathrm{~mm}$.

Рис. 14-17. Lycoprogentes, голотипы, самцы: 14-15 - L. holzschuhi sp.n.; 16-17 - L. aurantiacus sp.n.; 14, 16 - общий вид; 15, 17 - эдеагус, снизу. Масштабная линейка: 0.5 мм.

\section{Xylobanellus cerasinus Kazantsev sp.n.}

Figs 18-20

MATERIAL: Holotype, $0^{7}$, E Laos, Hua Phan prov., Ban Saleui, Phou Pan Mt., $20^{\circ} 122 \mathrm{~N}, 104^{\circ} 01^{\prime} \mathrm{E}, 1300-1900 \mathrm{~m}, 1-31.05 .2011$, C. Holzschuh leg. (ICM); paratypes: $20^{7} 0^{7}, 7$ 우, same label (ICM).

DESCRIPTION. Male. Dark brown; pronotal margins and carinae and elytra reddish brown; elytral pubescence red.

Vertex slightly convex, with actually no antennal prominence. Eyes relatively small, with interocular distance ca. 1.6 times greater than eye diameter. Labrum transverse, medially deeply emarginate. Ultimate palpomeres elongate, widened and flattened distally. Antennal sockets separated by relatively broad lamina. Antennae attaining to elytral six sevenths, noticeably narrowing distally, almost filiform; antennomeres 4-6 feebly dentate; with antennomere 2 about as long as wide and almost 3 times shorter than antennomere 3; antennomere 31.4 times shorter than antennomere 4, antennomeres 4-11 with short dense decumbent pubescence (Fig. 18).

Pronotum transverse, ca. 1.3 times as wide as long, bisinuate basally and semi-circular anteriorly, with almost straight sides and small acute posterior angles; median areole narrow, attaining anterior four fifths; lateral carinae conspicuously bent in the middle. Scutellum subquadrate, trapezoi- dal, narrowing distally, truncate at apex (Fig. 18).

Elytra long, 3.4 times longer than wide at humeri, with four equally developed primary costae, interstices with a row of even elongate cells; pubescence double: short scarce uniform and longer erect separate hairs mostly on longitudinal costae (Fig. 18).

Aedeagus with narrow, constricted in distal third and strongly bent, in lateral view, median lobe, with slightly dilated, in lateral view, apex; parameres as long as median lobe, constricted at sides in the middle; phallobase semicircular, with noticeable proximal dent (Figs 19-20).

Female. Similar to male, but eyes somewhat smaller and antennae slightly shorter.

Length: $5.2-7.5 \mathrm{~mm}$. Width (humerally): $1.2-1.8 \mathrm{~mm}$.

ETYMOLOGY. The name of the new species is derived from the Latin for «cherry red», alluding to its coloration.

DIAGNOSIS. Xylobanellus cerasinus sp.n. differs from other members of the genus by the bicoloured pronotum, dark reddish brown elytra covered with red pubescence (Fig. 18), as well as by the narrow, constricted in distal third and strongly bent, in lateral view, median lobe of the aedeagus, with slightly dilated, in lateral view, apex and subequal in length to median lobe parameres, constricted at sides in the middle (Figs 19-20). 


\section{Xylobanellus rubeus Kazantsev sp.n.} Figs 21-22

MATERIAL: Holotype,,+ E Laos, Hua Phan prov., Ban Saleui, Phou Pan Mt., $20^{\circ} 122 \mathrm{~N}, 104^{\circ} 01^{\prime} \mathrm{E}, 1300-1900 \mathrm{~m}, 1-31.05 .2011$, C. Holzschuh leg. (ICM); paratypes: 8 우, same label (ICM)

DESCRIPTION. Female. Dark brown; pronotum, except bottom of median areole, and elytra red; head posteriorly reddish brown.

Vertex slightly convex, with a pair of shallow impressions behind antennal prominences, glabrous, with scarce fine punctures. Eyes small, with interocular distance ca. 1.7 times greater than eye diameter. Labrum short, transverse, medially emarginate. Ultimate palpomeres elongate, strongly widened and flattened distally. Antennal sockets separated by relatively broad lamina. Antennae attaining to elytral two thirds, almost filiform, conspicuously narrowing distally, with antennomere 2 slightly wider than long and almost 4 times shorter than antennomere 3 ; antennomere 31.15 times shorter than antennomere 4, antennomeres 4-11 with short dense decumbent pubescence (Fig. 21).

Pronotum transverse, ca. 1.7 times as wide as long, trapezoidal, bisinuate basally and convex anteriorly, with long acute posterior angles; median areole relatively broad, attaining anterior three fourths; lateral carinae feebly bent near the areole. Scutellum subquadrate, trapezoidal, narrowing distally, emarginate at apex (Fig. 21).

Elytra long, 3.75 times longer than wide at humeri, with four complete primary costae, costa 4 stouter in proximal half; interstices with a row of even transverse cells; pubescence double: minute scarce hairs at bottom of cells and longer erect separate hairs mostly on longitudinal costae (Fig. 21).

Valvifers free, short and robust, styli prominent, coxites free, sternite 10 free, elongate, shield-shaped; pair of accessory glands elongate, spermatheca elongate, with twisted proximal end (Fig. 22)

Male. Unknown.

Length: $6.7-8.5 \mathrm{~mm}$. Width (humerally): $1.5-2.0 \mathrm{~mm}$.

ETYMOLOGY. The name of the new species is derived from the Latin for «raspberry red», alluding to its coloration.

DIAGNOSIS. Xylobanellus rubeus sp.n. may be easily distinguished from the congeners by the uniformly red pronotum and elytra and strongly transverse trapezoidal pronotum with long acute hind angles (Fig. 21).

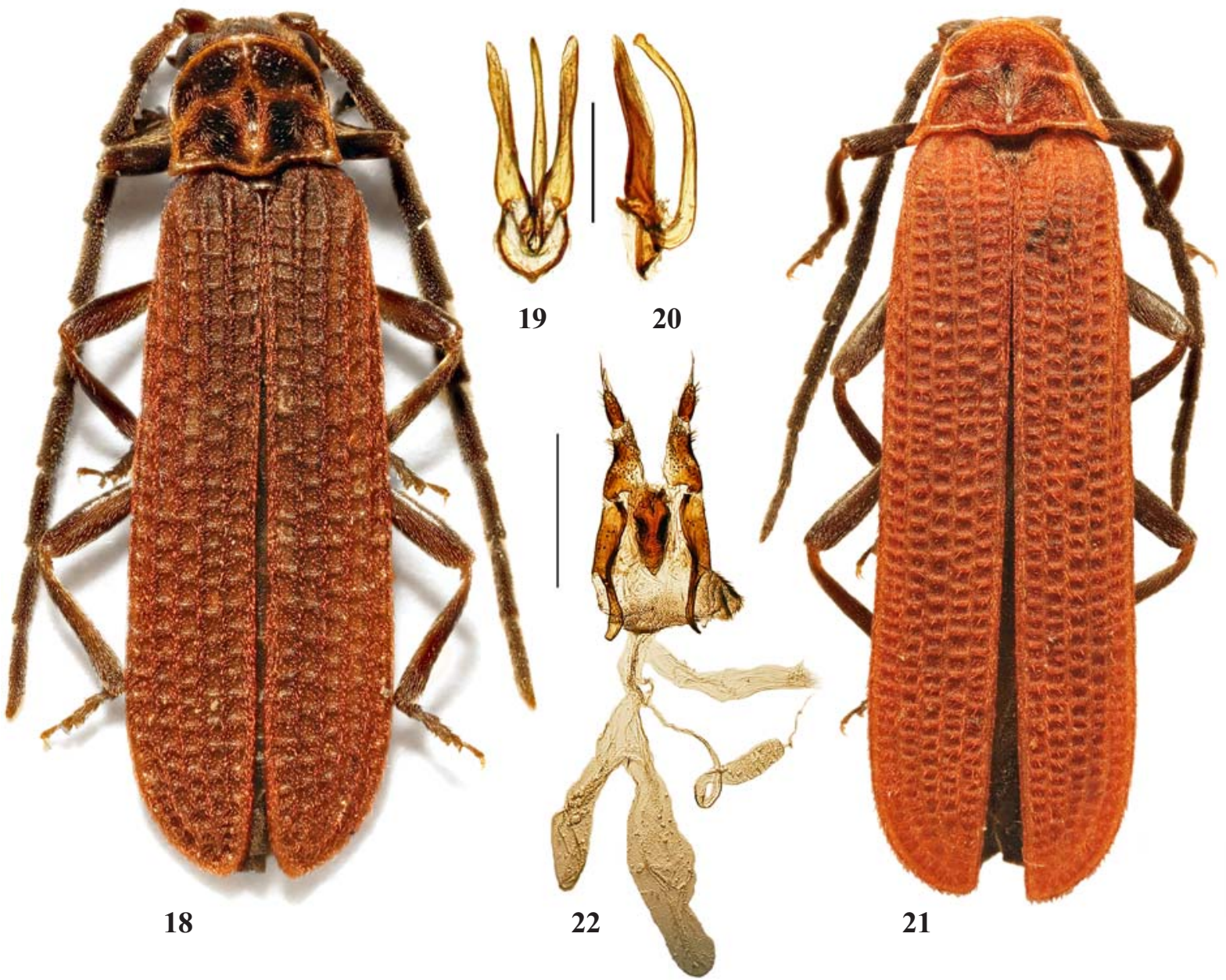

Figs 18-22. Xylobanellus, holotypes: $18-20-X$. cerasinus sp.n.; 21-22 - X. rubeus sp.n.; 18, $21-$ general view, dorsally; 19-20 aedeagus; 22 - female external genitalia; 19 - dorsally; 20 - laterally; $18-20$ - male; $21-22$ - female. Scale: 0.5 mm.

Рис. 18-22. Xylobanellus, голотипы, самцы: 18-20 - X. cerasinus sp.n.; 21-22 - X. rubeus sp.n.; 18, 21 - общий вид, сверху; 1920 - эдеагус; 22 - внешние женские гениталии; 19 - сверху; 20 - сбоку; 18-20 - самец, 21-22 - самка. Масштабная линейка: 0.5 MM. 


\section{Dilophotes umbellifer Kazantsev sp.n.}

Figs 23-24

MATERIAL: Holotype, $0^{7}$, N Vietnam: Lai Chau prov., Hoang Lien Son N.P., $1980-2070 \mathrm{~m}, 22.338^{\circ} \mathrm{N}, 103.779^{\circ} \mathrm{E}, 7 . V .2013$, A. Prosvirov leg.; paratype,, , same label (ICM).

DESCRIPTION. Male. Black; pronotum, except narrow median stripe, and elytra red.

Vertex convex, finely and densely punctured, with narrow median furrow. Eyes small, interocular distance ca. 1.8 times greater than eye diameter. Labrum short, transverse, semicircular anteriorly. Ultimate palpomeres slender, slightly longer than wide, conspicuously widened and flattened distally. Antennal sockets separated by narrow lamina. Antennae nearly attaining to elytral apices, from antennomere 3 broad and dentate, narrowing distally; antennomere 2 small, transverse, 5 times shorter than antennomere 3 , antennomere 3 ca. 1.6 times shorter than antennomere 4; antennomeres $3-$ 11 with short dense decumbent pubescence (Fig. 23).

Pronotum transverse, ca. 1.5 times as wide as long, bisinuate basally, slightly convex anteriorly, with almost straight sides and small acute posterior angles. Scutellum transverse, trapezoidal, feebly emarginate at apex (Fig. 23).

Elytra long, 3.8 times longer than wide at humeri, almost parallel-sided, dehiscent below middle, with three prominent primary costae, with costa 1 well developed in proximal three fifths (Fig. 23).

Aedeagus with relatively short median lobe provided with umbrella-like appendage; phallobase elongate, narrow, ca. 1.4 times length of median lobe, asymmetric (Fig. 24).

Female. Similar to male, but antennae considerably narrower.

Length: $8.6-8.8 \mathrm{~mm}$. Width (humerally): $1.9-2.0 \mathrm{~mm}$.

ETYMOLOGY. The name of the species is derived from the Latin for «carrying an umbrella», alluding to the shape of its aedeagus.

DIAGNOSIS. Dilophotes umbellifer sp.n. differs from other members of the genus by the red pronotum and elytra and broad antennomeres (Fig. 23), as well as by the peculiar umbrella-shaped median lobe of the aedeagus (Fig. 24).

\section{Lyponia (Weiyangia) simplex Kazantsev sp.n.} Figs 25-27 (ICM).

MATERIAL: Holotype, O, C Vietnam, env. Khe Sanh, 4.II.1991

DESCRIPTION. Male. Black; pronotum, except fuscous bottom of median impression, and elytra red.

Vertex flat, finely and scarcely punctured. Eyes small, interocular distance ca. 1.6 times greater than eye diameter.

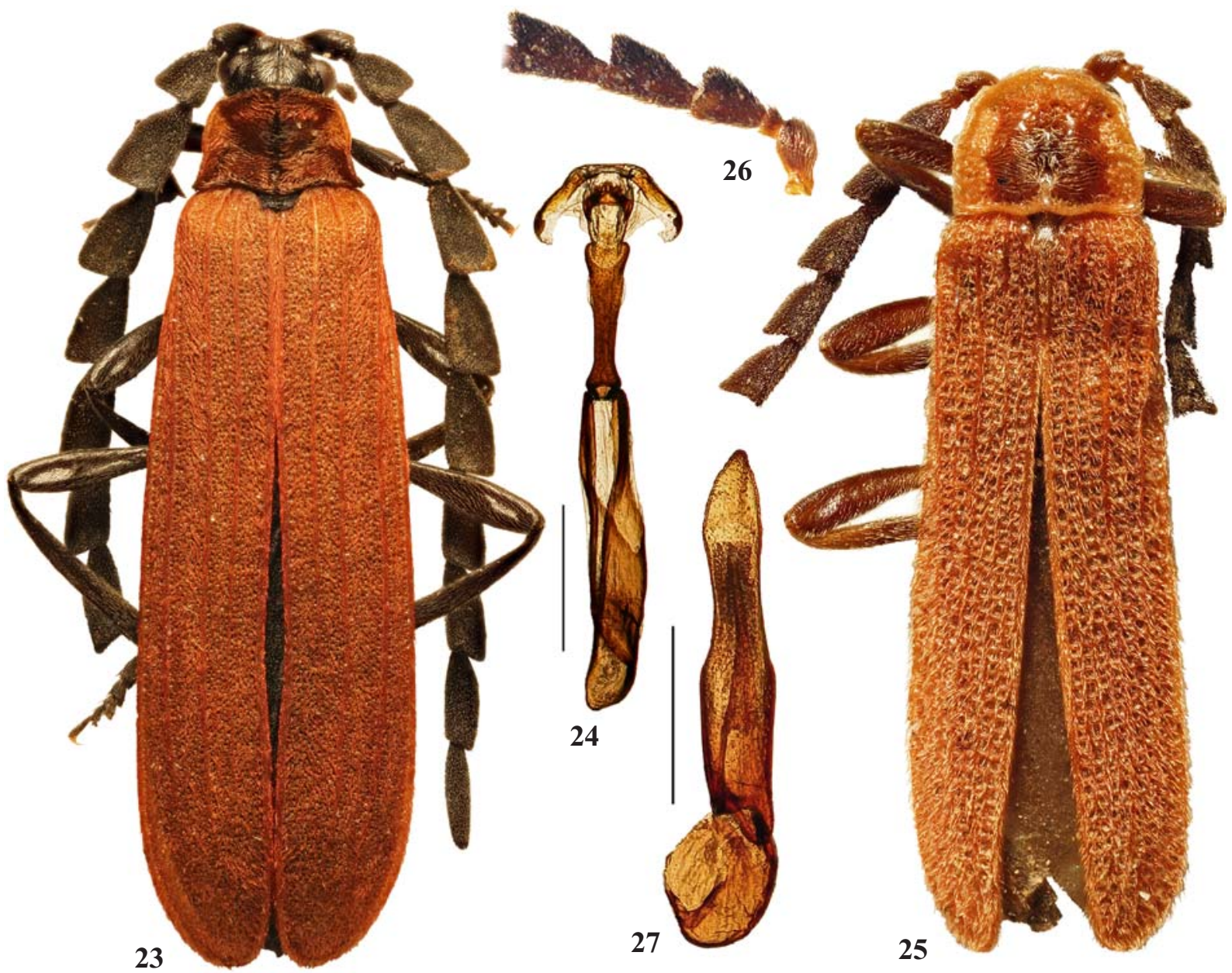

Figs 23-27. Dilophotes and Lyponia, holotype males: 23-24 - D. umbellifer sp.n.; 25-27 — L. (Weiyangia) simplex sp.n.; 23, 25 general view, dorsally; 26 - antennomeres $1-5 ; 24,27$ - aedeagus ventrally. Scale: $0.5 \mathrm{~mm}$.

Рис. 23-27. Dilophotes и Lyponia, голотипы, самцы: 23-24 - D. umbellifer sp.n.; 25-27 — L. (Weiyangia) simplex sp.n.; 23, 25 общий вид, сверху; 26 - антенномеры 1-5; 24, 27 - эдеагус, снизу. Масштабная линейка: 0.5 мм. 
Antennal sockets separated by narrow lamina. Antennae from antennomere 3 flattened and dentate, narrowing distally; antennomere 2 small, transverse, 4.3 times shorter than antennomere 3 , antennomere 3 ca. 1.3 times shorter than antennomere 4; antennomeres 3-11 with short dense decumbent pubescence (Figs 25-26).

Pronotum transverse, ca. 1.3 times as wide as long, feebly bisinuate basally, convex anteriorly; sides parallel in posterior two fifths, then abruptly narrowing anteriorly; posterior angles inconspicuous; disk with obscure median impression. Scutellum elongate, concave at sides, triangularly emarginate at apex (Fig. 25).

Elytra long, 3.5 times longer than wide at humeri, almost parallel-sided, with four primary costae, costa 1 weakened in distal half, costa 3 noticeable only in proximal fourth; interstices with double rows of small subquadrate cells; pubescence along costae short, dense and erect, bottom of cells hairless (Fig. 25).

Aedeagus with elongate and almost symmetric median lobe, narrowing distally and constricted in distal two fifths; phallobase asymmetric, oval, slightly longer than wide (Fig. 27).

Female. Unknown.

Length: $6.5 \mathrm{~mm}$. Width (humerally): $1.6 \mathrm{~mm}$.

ETYMOLOGY. The name of the species is derived from the Latin for «simple», alluding to the shape of its aedeagus.

DIAGNOSIS. Lyponia (Weiyangia) simplex sp.n. differs from other members of the subgenus by the broader and more dentate antennomeres (Fig. 26) and triangular meso- and metatrochanters with pronounced hind angles, as well as by the narrowing distally and constricted in distal two fifths median lobe of the aedeagus (Fig. 27).
ACKNOWLEDGEMENTS. It is my pleasant duty to express gratitude to Patrick Grootaert (Brussels, Belgium), Carolus Holzschuh (Villach, Austria) and Alexander Prosvirov (Moscow) for the opportunity to study the lycid material collected during their expeditions to northern Indochina and China.

\section{References}

Bocák L., Bocáková M. 1991. Notes on some Palaearctic and Oriental representatives of the tribe Erotini (Coleoptera, Lycidae) // Acta Entomologica Bohemoslovaca. Vol.88. P.313326.

Bocáková M., Bocák L. 2007. Lycidae // I. Löbl, A. Smetana (eds.). Catalogue of Palaearctic Coleoptera. Vol.4. Stenstrup: Apollo Books. P.211-224.

Kazantsev S.V. 1996. A review of Pyropterus subgen. Helcophorus Fairmaire with the description of two new oriental species (Lycidae, Coleoptera) // Elytron. Vol.10. P.81-88.

Kazantsev S.V. 2002. Supplementary notes to the revision of the genus Lyponia Waterhouse, 1878 (Coleoptera: Lycidae) with description of new taxa // Russian Entomological Journal. Vol.11. No.2. P.197-206.

Kazantsev S.V. 2004. Phylogeny of the tribe Erotini (Coleoptera, Lycidae), with descriptions of new taxa // Zootaxa. No.496. P.148.

Kazantsev S.V. 2013. A new fossil genus of net-winged beetles, with a brief review of amber Lycidae (Insecta: Coleoptera) // Zootaxa. Vol.3608. No.1. P.94-100.

Kleine R. 1933. Pars 123: Lycidae // Coleopterorum Catalogus auspiciis et auxilio W. Junk editus a Schenkling. Berlin: W. Junk. 145 p. 